Síntese - Rev. de Filosofia

v. 32 N. 103 (2005): 335-370

\title{
METAMORFOSES DO ESTADO \\ CONSTITUCIONAL E A TEORIA HEGELIANA \\ DA CONSTITUIÇÃO
}

\author{
A gemir Bavaresco ${ }^{1}$, \\ Ernani Schmidt ${ }^{2}$ \\ e Sérgio B. Christino ${ }^{3}$
}

Resumo: Os Estados nas suas relações internacionais são levados a possuir uma estratégia de inserção mundial soberana. Daí a pergunta: Qual é a função da Constituição para inserir o Estado soberanamente na política internacional, buscando relações globais e plurais, em defesa dos interesses nacionais e da formação de um novo espaço político internacional de caráter democrático? Para responder a esta inquietação, analisamos a experiência histórica dos três modelos de Estado constitucional modernos: Liberal de Direito, Social de Direito e Democrático de Direito, expondo em seguida o debate contemporâneo entre liberais e comunitários e suas posições a respeito da Constituição. Face ao nosso problema temos duas posições. A resposta convencional promove o fortalecimento de blocos regionais e, portanto, a integração entre os países membros. A teoria hegeliana da Constituição, por seu lado, diante deste cenário da mundialização, prioriza

\footnotetext{
${ }^{1}$ Professor do Instituto Superior de Filosofia/UCPel.

2 Professor da Escola de Direito/UCPel.

${ }^{3}$ Advogado e Pós-Graduado em Filosofia/UFPel.
} 
os elementos da identidade constitucional como uma garantia e condição de reconhecimento mundial. 0 Estado, bem definido, constitucionalmente, poderá fazer uma inserção soberana e autônoma neste atual estágio de correlação de forças, tanto em nível regional, como mundial.

Palavras-Chave: Constituição, Modelos constitucionais, Liberais e Comunitários, Filosofia do Direito, Mundialização.

Abstract: All States, in their international relations, aim to adopt a sovereign strategy of global insertion. This leads to the following question: What is the role played by the Constitution in incorporating a sovereign State into international politics, when searching for global and plural relations aimed at defending national interest within a new international political context of a democratic type? To answer this query, we have analyzed the historical experience of three contemporary models of the constitutional State: Rule of Law, Social governance and Democratic governance. The contemporary debate opposing liberals to communitarians as well as their differing positions concerning the Constitution will also be exposed in this work. We are confronted with two standpoints. On the one hand, the conventional answer which promotes the strengthening of regional blocks and, therefore a better integration of member states and, on the other hand, the Hegelian Constitution theory which, in the face of globalization, prioritizes constitutional identity elements as a guarantee and condition of global recognition. A constitutionally well-defined State will have the capacity of incorporating itself, in a sovereign and autonomous way, into the current stage of correlation of forces, both nationally and globally.

Keywords: Constitution, Constitutional models, Liberals and Communitarians, Philosophy of the Law, globalization.

\section{Introdução}

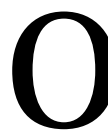

objeto do presente trabalho é acompanhar a evolução histórica dos modelos de Estado moderno e suas formulações constitucio nais correspondentes, com vistas a oferecer contribuições ao debate que enfoca o papel do Estado-Nação, em uma sociedade internacional, na qual, hoje, inegavelmente, se inserem, e que é regida por normas próprias. Esta difícil relação é vista por uns como que de avassalamento da soberania das comunidades políticas autônomas, na forma em que hoje são conhecidas.

Na primeira parte, revisaremos as características próprias do Estado, naquelas feições mais proeminentes durante 0 trato histórico que medeia entre a modernidade e o contemporâneo, quais sejam, o Estado de Direito Liberal, o Estado Social de Direito e o Estado Democrático de Direito, sublinhando, sempre, o marco jurídico-constitucional em consonância com estas inflexões históricas. 
No segundo momento, pautaremos um segmento do forte debate entre os modelos liberais e comunitaristas, no que tange às exigências normativas, relacionadas ao pluralismo das sociedades democráticas atuais.

$\mathrm{Na}$ terceira parte, examinaremos aspecto da maior relevância no sistema da Filosofia do Direito de Hegel, qual seja, a teoria hegeliana da Constituição, o que possibilita entender as bases da soberania interna e externa da configuração política do Estado nacional.

Por último, examinaremos qual a contribuição que pode ser oferecida pela teoria hegeliana da Constituição à situação dos Estados no contexto da chamada mundialização. 0 modelo de Constituição, produzido durante a formação do Estado-Nação moderno-contemporâneo, pode ainda garantir uma atuação rápida e eficiente do Estado, cumprindo suas legítimas e indispensáveis funções face à mundialização?

\section{1 - Três modelos de Estado Constitucional}

Bobbio, em Estado, Governo, Sociedade - Por uma teoria geral da política, aponta que se costuma chamar constitucionalismo à teoria e à prática dos limites do poder; que tais teorias e práticas se encontram expressas nas diferentes Constituições (BOBBIO, 1989, 139). De fato, esta é uma, ou a primeira aproximação com a relação que envolve os conceitos de Estado e Constituição.

Tércio Sampaio Ferraz Júnior ensina que a abordagem desse tema deve permitir que se explicite, por meio da rede normativa do texto da Constituição, qual o modelo estatal que é realmente efetivado, tendo em conta esta realização, tanto o aspecto histórico que condiciona a Carta Constitucional, quanto o prognóstico normativo que ela autoriza.

É, assim, ir-se além do descritivismo, que vê no termo Constituição apenas a organização real do governo, para esmiuçar-Ihe os aspectos funcionais, ou seja, enquanto documento continente de deveres normativos prognosticados.

Merece trazer à tona a formulação de Carl Schmitt ${ }^{4}$, cotejada por JeanFrançois Kervégan (KERVÉGAN, 1992, 68-69). Ao tratar da estreita relação entre Estado e Constituição, Carl Schmitt, em sua obra Teoria da Constituição, preocupa-se em alcançar uma significação mais técnica do que seja Constituição. Nesse sentido, distingue quatro tipos de concepções: um

\footnotetext{
${ }^{4}$ A tardia e renegada adesão de Carl Schmitt ao nacional-socialismo teve até hoje o condão de gerar um efeito sombrio sobre toda a obra do grande juris-filósofo e esta obra não merece reconhecimento por qualquer condescendência revisionista, mas, apenas, porque, inicialmente, é uma radical contribuição crítica ao liberalismo e, porque, contribui para esclarecer a significação profunda da filosofia política hegeliana, bem como, para que se possa medir a atualidade desta.
} 
conceito absoluto, um conceito relativo, um conceito positivo e um conceito ideal de Constituição, dos quais, segundo Kervégan, Schmitt adota o primeiro e o terceiro de maneira complementar.

Para Schmitt, no sentido do conceito absoluto, o Estado e a Constituição são iguais. 0 Estado é Constituição; esta é o próprio modo de ser do Estado, de maneira que, se uma dada Constituição, correspondente a um determinado Estado, desaparecesse, o mesmo deixaria de existir. Neste sentido a Constituição é a vida concreta do Estado, sua alma. Em nota apartada, Kervégan faz ver que esta definição evoca o conceito hegeliano de Estado, conforme contido nos termos dos parágrafos 272 e 274 da Filosofia do Direito.

Segundo o conceito positivo, para Schmitt, a Constituição compreende uma decisão simultânea sobre o tipo e a forma de unidade política. Com isso, destaca Kervégan, o conceito positivo schmittiano de Constituição expressa-se dentro do que se chamou de decisionismo, uma vez que a Constituição, nesta perspectiva, é resultado de um ato de um poder constituinte, que pode, indiferentemente, ser proveniente do povo ou proveniente de um monarca. Tal ato, por sua vez, decorre da vontade primeira, que atribui sentido e valor ético e jurídico à constituição das estruturas do Estado. Logo, é fruto de uma decisão.

0 termo positivo, na abordagem de Schmitt, conforme Kervégan não é empregado na acepção positivista tradicional (do normativismo), mas na mesma acepção hegeliana de positivação, ou seja, daquilo que é posto, instituído. A Constituição, assim, é positiva, porque emana de um querer constituinte, existencial. Portanto, guarda em si um princípio "ativo de um processo dinâmico de energias, um elemento do devenir, mas não um procedimento regulado por prescrições normativas" (RUSSOMANO, 1972, 56). Não é um mero dever ser, diríamos.

É nesta perspectiva que examinaremos as metamorfoses do Estado Constitucional, como aquela figura que, historicamente, se coloca a partir da modernidade aos dias atuais.

\section{1 - 0 Modelo do Estado Liberal de Direito}

O Estado Liberal de Direito surgiu fruto da crítica ao Estado Monárquico Absolutista, dos séculos XVII e XVIII, no qual o rei era o soberano e exercia a plenitude do poder, sem nenhuma limitação de ordem constitucional; a origem de seu poder era dita de natureza divina; um Estado onde o soberano, concentrando todo o poder, por todo o tempo, tinha direito sobre a vida, a liberdade e a propriedade de todos seus cidadãos, e ademais, determinava, ainda, a vida econômica. O rei tornara-se, então, detentor de uma vontade incontrastada em face de outros poderes [...] deixa de existir uma concorrência entre poderes distintos, e ocorre uma conjugação dos mesmos em mãos da monarquia, do rei, do soberano (Bolzan de Morais, 2002, 24). 
O liberalismo que surge a partir do enfrentamento com o sistema monarquista-feudal, além da dimensão política, alcançará, também, as dimensões econômico-filosóficas e será fomentado por pensadores como Rousseau, Sieyès, Montesquieu, Diderot, Voltaire, David Smith, David Ricardo, John Locke etc.

Todos estes filósofos e pensadores consolidaram um balanço crítico à sociedade absolutista-monarquista que culminou, na Revolução Francesa, processo revolucionário de caráter político social que, de certa forma, coincidiu com o fenômeno de caráter científico-tecnológico: a Revolução Industrial; ambos eventos históricos deram origem simultaneamente, por um lado, a um novo tipo de sociedade: a sociedade capitalista e, por outro, a um novo tipo de Estado: o Estado Liberal de Direito.

O Estado Liberal de Direito tem, como principais características, o seguinte:

a) O liberalismo estabelece uma dualidade entre o Estado e a sociedade; estas instâncias são concebidas como sistemas autônomos e claramente discerníveis uma em relação à outra, ambas com suas próprias racionalidades e com limites claramente estabelecidos. Enquanto a sociedade se autodetermina em um ordenamento natural que obedece a suas próprias leis de funcionamento, o Estado é uma criação; um fruto histórico da ação humana.

O livre funcionamento da sociedade supõe a proteção de alguns direitos entendidos como inalienáveis e prévios à implementação do Estado, são os chamados direitos fundamentais do homem; estes são organizados em torno de idéias básicas,tais como a liberdade, a propriedade e a segurança do indivíduo.

À liberdade concernem as esferas das liberdades civis, econômicas, de pensamento e de oposição. A liberdade plenamente exercida nessas esferas assegura ao indivíduo os direitos de discussão e de participação, que são denominados direitos políticos e que se materializam na liberdade de imprensa, de reunião e de associação.

No contexto da visão liberal, a propriedade é aquele direito inviolável e sagrado, nos termos em que a definiu $A$ Declaração Universal dos Direitos do Homem. Por outro lado, a propriedade habita o próprio centro do pensamento iluminista burguês, constituindo mesmo a condição para que se expresse, adequadamente, a liberdade individual.

A segurança é compreendida apenas como a função de garantia que assegura o desdobramento da liberdade e da propriedade.

b) Provavelmente, a contribuição mais positiva do Estado Liberal de Direito para o avanço da humanidade tenha sido sua dimensão jurídico-política, que se expressa tanto no estabelecimento do princípio de que a soberania é consubstanciada no povo (ou nação), quanto no direito ao voto, na democracia representativa, na divisão de poderes, na criação de um Estado não arbitrário, portanto, de um Estado Constitucional. 
Merece destacar a dogmática divisão de poderes, que teve em Montesquieu seu porta-voz, e que afirma, em face do poder absoluto e total do soberano, que a única forma de controlar o poder está em outro de mesma dimensão e natureza. Concebe, então, o poder do Estado dividido em três poderes: o legislativo, o executivo e o judiciário, que devem controlar-se entre si.

0 absolutismo pregava que os atos do rei ou soberano não estavam limitados pelas leis; em oposição, o liberalismo advogará a concepção da autoridade da lei, que será elevada à categoria de princípio, declarando que todo ato de Estado deveria ser um ato jurídico que derivasse sua força de lei aprovada pelo Parlamento, instituição através da qual se manifesta de modo completo a vontade popular. Na conhecida fórmula de Rousseau, a lei é a expressão da vontade geral.

Com a teoria da vontade geral, Rousseau desloca o exercício da soberania das mãos do monarca para as da nação, para as mãos da burguesia (BOLZAN DE MORAIS, 2002 25). A soberania, então, passa a caracterizarse como:

... um poder que é juridicamente inconstratável, pelo qual se tem a capacidade de definir e decidir acerca do conteúdo e da aplicação das normas, impondo-as coercitivamente dentro de um determinado espaço geográfico, bem como fazer frente a eventuais injunções externas" (BOLZAN DE MORAIS, 2002, 25).

Destaca, ainda, o mencionado autor, que a soberania passa, desde então, a gozar das prerrogativas da indivisibilidade, da imprescritibilidade e da inalienabilidade, sendo esta, por fim, a soberania da modernidade, típica do Estado Nação.

c) Quanto à dimensão econômica, ressalta a clássica posição liberal burguesa de que ao Estado incumbe apenas assegurar a liberdade de competição entre as forças da sociedade. 0 Estado deve zelar, para que as leis de mercado sejam cumpridas, não devendo intervir no social, senão na violação destas.

d) $\mathrm{Na}$ dimensão social, as políticas sociais promovidas pelo Estado Liberal de Direito se resumem num intento sutil cujo fim é o de paralisar o progresso de uma visão socializante do Estado, neste sentido, as políticas sociais de Bismarck, implementadas na Alemanha dos anos 1880, são 0 exemplo mais patente. 0 Chanceler de Ferro estabeleceu as primeiras leis de seguro social no mundo, ao criar os seguros doença, acidente, por idade e invalidez permanente, os quais podem ser considerados antecedentes do Estado do Bem Estar Social moderno.

De maneira que se pode caracterizar o constitucionalismo correspondente ao Estado Liberal de Direito, como sendo aquele, no qual as Constituições voltaram-se a estabelecer limites ao poder do Estado, seja quanto ao respeito à lei, seja na elaboração desta; sendo que quanto a este último, asse- 
gurando que sua motivação fosse 0 bem dos governados, embora ainda na perspectiva do indivíduo.

Aparecem, então, institutos limitando a intervenção estatal na liberdade e na propriedade dos cidadãos, consolidando a generalidade da lei e sua necessária anterioridade; a irretroatividade da lei e as garantias necessárias ao exercício da magistratura com independência em relação às esferas do Executivo e do Legislativo.

Sendo que tal constitucionalismo vai refletir, por um lado, a perspectiva social correspondente à eminência da burguesia mercantil, por outro, a expressão da vontade instituinte desta classe, no sentido de desenhar qual o tipo de estruturação do Estado que melhor viria a atender suas aspirações do ponto de vista ético-jurídico. De maneira que ressalta a aplicação dos conceitos schmitteanos complementares acima mencionados, ou seja, 0 conceito absoluto e o conceito positivo de constituição.

\section{2 - 0 Modelo do Estado Social de Direito}

0 nascimento do Estado Social de Direito é o resultado da convergência de vários fatores, tais como:

- Iuta da classe trabalhadora surgida no contexto da $1^{\text {a }}$ Revolução Industrial, que, principalmente pela aplicação dos princípios econômicos e políticos do liberalismo, passa a ser objeto de uma superexploração chegando, em muitos casos, a situações piores que às da escravidão;

- o surgimento de um pensamento crítico-científico que, principalmente a partir de K. Marx e F. Engels, passa a questionar fortemente o sistema capitalista e o Estado Liberal de Direito;

- a vitória de Lenin e Trotsky na Rússia, com a Revolução de abril de 1917, que resultou na implantação da União das Repúblicas Socialista Soviéticas e um tipo novo de Estado: o Socialista, que atribui ao Estado funções socialmente relevantes e cuja mera existência, em si mesmo, passa a significar uma crítica contundente ao Estado Liberal de tipo capitalista.

- a Revolução M exicana que começou em 1910 e que culminou em 1917 com uma nova Constituição: a primeira no mundo a consagrar direitos sociais aos trabalhadores assalariados (Artigo 123) e direitos aos camponeses (Artigo 27);

- na Alemanha, em 1919, era aprovada a Constituição de Weimar, a qual estabelecia, como obrigação do Estado, levar a cabo ações positivas para dar satisfação e execução aos direitos sociais;

Inegavelmente, todos este fatores contribuíram à reforma do Estado de Direito Liberal e a transformação deste, em maior ou menor medida, no Estado Social de Direito. 


\subsubsection{As novas bases do pensamento para o Estado Social de Direito}

a) A contribuição do keynesianismo

A partir da crise de 1929, surge uma nova concepção de Estado, sob os auspícios do economista inglês J. M. Keynes, prêmio Nobel em Economia. Segundo este pensador, os principais defeitos da sociedade são sua inabilidade para prover oferta de pleno emprego e a distribuição arbitrária e desigual da riqueza e da renda. Para corrigir isto, o economista inglês propôs um papel mais ativo por parte do Estado, transformando este, por um lado, em uma entidade geradora de empregos, através de grandes investimentos públicos e, por outro, colocando a atividade estatal na condição de protagonista no processo de redistribuição de renda, através do sistema de impostos progressivos.

Realmente, Keynes demonstrou objetivamente que o capitalismo não poderia sobreviver, se continuasse guiado pelos mecanismos de mercado, conforme prescrevia a teoria liberal clássica.

b) A contribuição da social-democracia

A social-democracia foi um movimento reformista dentro do pensamento socialista. Esta corrente, teoricamente, preserva vários pontos do socialismo revolucionário, mas na prática os abandona, conservando apenas os programas de grande benefício social, mantendo, ao final, a essência do capitalismo.

A concepção de Estado da social-democracia é a de promotor do desenvolvimento e seu programa pugna pela construção de sociedades onde sejam viabilizadas as democracias política e econômica. Deve ainda o Estado desenvolver e estender a propriedade pública, principalmente em áreas ou setores estratégicos e desenvolver a forma de propriedade social, como as cooperativas de produção e de consumo.

\subsubsection{Características do Estado Social de Direito}

A melhoria dos sistemas de seguro social;

- O desenvolvimento do tributo progressivo;

- A implementação de políticas fiscais e monetárias (nos termos concebidos pelo keynesianismo).

É certa, portanto, a afirmação de que o Estado Social de Direito é, na verdade, um sucessor político do Estado Liberal de Direito, e não um paradigma que contradiga a este último.

Isto não quer dizer, porém, que a tarefa a que se propõe o estado Social de Direito, quer no campo político, quer no econômico, seja menos relevante. De fato, o Estado é uma entidade que deve aperfeiçoar a democracia, pois 
esta é a forma mediante a qual se expressa a liberdade, e como não se pode pensar na efetividade da democracia política sem a efetiva democracia econômica, o Estado Social de Direito se propõe a esta tarefa de harmonizar democracia política como método do compromisso das regras; e democracia social como a realização do princípio de igualdade na sociedade.

Em suma, o constitucionalismo correspondente ao Estado Social de Direito resulta do debate estabelecido, a partir do segundo período pós-guerra, entre as concepções de inspiração hegeliana e as de inspiração kantiana; as primeiras, influenciadas pelas contribuições do já mencionado Carl Schmitt, bem como de Rudolf Smend. E as últimas por todos aqueles autores tributários da Teoria Pura do Direito de Hans Kelsen.

Assim, prevalecerá, no texto Constitucional deste período, a idéia da Constituição como sendo ligada à vida política orgânica do Estado, ou seja, a Constituição como totalidade, que não mais se limita ao aspecto normativo. Entrelaçam-se, nos textos Constitucionais, os direitos individuais fundamentais - herança do liberalismo -, com os direitos econômicos e sociais. De maneira que, os direitos fundamentais econômicos e sociais derivam da Constituição e não de uma lei no sentido geral e abstrato, aliás, a lei neste contexto passa à condição de instrumento de ação (STRECK- MORAIS, 2000, 89); e, porque os comandos constitucionais não são mais garantias meramente abstratas, o poder Executivo e o Legislativo estão agora vinculados.

\section{3 - 0 Modelo do Estado Democrático de Direito}

A partir dos dois modelos anteriores, algumas situações históricas têm apresentado transformações significativas, conforme registram os autores acima mencionados - Lenio Luiz Streck e José Luis Bolzan de Morais. Enquanto no Estado Liberal de Direito, o centro da decisão constituinte aponta para o Legislativo (estabelecendo os chamados direitos negativos) e no Estado Social de Direito, institui-se imposições ao Executivo, em face da necessidade de realizar políticas públicas e sustentar a intervenção do Estado na economia, apontam os autores que uma nova grade de idéias passa a implementar-se como incorporação de características novas aos dois momentos anteriores. Assim, no chamado Estado Democrático de Direito, 0 foco da vontade constituinte se direciona para o Judiciário.

Portanto, em face das omissões do Executivo e da inércia do Legislativo, pode/ deve o Judiciário supri-las, mediante a utilização dos mecanismos jurídicos previstos na Constituição, que estabeleceu o Estado Democrático de Direito. Veja-se a importância de instrumentos jurídicos como a ação popular, a ação civil pública, o mandado de injunção, ação direta de inconstitucionalidade, mandado de segurança coletivo etc.

As principais questões incorporadas de maneira decisiva aos modelos tradicionais pelo novo Estado Democrático de Direito são as da igualdade e 
da solidariedade. Pela primeira, busca-se assegurar as condições mínimas de vida digna ao cidadão e à comunidade, enquanto que, pela segunda, busca-se atender aos problemas relativos à qualidade de vida dos indivíduos e da coletividade no seu conjunto.

Aqui, o constitucionalismo encontra-se permeado pela noção de que a Lei tem o conteúdo de transformação do status quo:

[...] o Estado Democrático de Direito carrega em si um caráter transgressor que implica agregar o feitio incerto da Democracia ao Direito, impondo um caráter reestruturador à sociedade e, revelando uma contradição fundamental com a juridicidade liberal a partir da reconstrução de seus primados básicos de certeza e segurança jurídicas, para adapta-los a uma ordenação jurídica voltada para a garantia/implementação do futuro, e não para a conservação do passado[...] (M ORAIS - STRECK, 2000, 94-95).

Merece destacar que a atual Constituição da República Federativa do Brasil, em seu art. $1^{\circ}$, traz estampado este comando que define a instalação e a realização de um modelo de Estado Democrático de Direito, enquanto resultado de uma situação histórica, em que o passado recente se reconhecia deficitário do exercício da democracia.

\section{4 - Considerações}

Vimos, pois, que as transformações históricas do modelo de Estado e do conjunto de condições sócio-jurídico-políticas que Ihes correspondem deságuam no Estado Democrático de Direito, até porque, considerar como implementado um modelo de Estado que correspondesse ao ideário neoliberal não parece adequado; primeiro porque esta corrente tem consolidada apenas uma crítica aos modelos precedentes, não tendo, entretanto, dado frutos em solo britânico na era Tatcher, e nem nos E.U.A., quando da era Reagan e, depois, porque no tocante aos países em desenvolvimento, tal modelo, embora imposto por exigências do capital internacional, tem sofrido enfrentamento constante por iniciativa de movimentos nacionalistas e/ ou inimigos da idéia de um Estado Constitucional mínimo, cuja perspectiva constitucional seja a do mero garantismo.

No entanto, se o Estado Democrático de Direito, e a Constituição Programática ou Dirigente (na acepção cunhada por Canotilho) são as formas históricas mais desenvolvidas, não resta dúvidas de que estes se vêem desafiados por uma outra realidade que se impõe; trata-se dos desafios que são propostos pelas sociedades pluralistas e multiculturais; da distensão que se estabelece entre a preservação do Estado-Nação e a implementação de unidades supranacionais. Em suma, importa saber se aquelas formas mais acabadas de Estado e Constituição restariam competentes para enfrentar tais desafios e ainda assegurar a implementação de uma democracia efetiva e um Estado de Direito inclusivo. 


\section{2 - Modelos contemporâneos para pensar a democracia e a Constituição}

Tendo observado distintos modelos de Estado Constitucional, pretende-se agora evidenciar características gerais de dois modelos de Constituição e Democracia que têm pautado uma fecunda controvérsia no pensamento político de nossos dias. Procura-se, para tanto, analisar aspectos que singularizam o chamado debate liberal-comunitário ${ }^{5}$, no qual é possível localizar uma complexa discussão sobre a Democracia e seus fundamentos, bem como sobre a Constituição e seu papel, sendo desenvolvida com 0 enfrentamento de distintas concepções de sujeito. Além dos modelos liberal e comunitário será abordado genericamente também o chamado pensamento crítico-deliberativo, o qual, conforme será visto, procura localizar as limitações das formulações originárias do debate para propor um modelo alternativo.

É de se salientar que a referência liberal-comunitária, mesmo que aparente ser restrita aos pensamentos expressos após considerável desenvolvimento do debate (três décadas), mantém-se precisa quanto aos propósitos da análise dos modelos pretendida no presente trabalho. Sobretudo, porque a expressão guarda precisão quanto às noções essenciais que motivam as discussões - as significações do pluralismo das sociedades democráticas contemporâneas. Ao desenvolver o que Wolkmer $(2001,172)$ designa compreensão filosófica do pluralismo (reflexão que tem como pressuposto a existência de várias fontes ou fatores aptos a explicar as condições histórico-sociais da vida humana, reconhecendo que esta é configurada em todos os seus aspectos constitutivos pela "diversidade, fragmentação, circunstancialidade, temporalidade, fluidez e conflituosidade"), emergem duas formulações contraditórias, acerca da característica pluralista das sociedades democráticas contemporâneas. 0 pensamento liberal elabora suas proposições sob a concepção de que estas sociedades são caracterizadas pelos conflitos suscitados pela variedade de concepções individuais em torno do bem e da vida digna. Por outro lado, o pensamento comunitário privilegia em suas análises a multiplicidade de identidades sociais. A formulação crítico-deliberativa intenta "superar" a contradição entre libe-

\footnotetext{
${ }^{5} \mathrm{~A}$ abertura do referido debate é reiteradamente atribuída à publicação de Uma Teoria da J ustiça, de J ohn Rawls (1971), a partir da qual se estabeleceu uma farta literatura passível de várias designações, dentre elas a comunitária - terminologia apta a reunir uma diversidade de estudos e elaborações vinculados exatamente no exercício de crítica ao liberalismo. Esta crítica ocorre tanto em relação ao liberalismo em geral quanto ao liberalismo de J ohn Rawls em particular. A este propósito ver: GARGARELLA, Roberto. Las teorias de la justicia después de Rawls: un breve manual de filosofia política. Barcelona: Paidós, 1999, 125. A origem deste debate, porém, pode ser localizada em confrontos teóricos de longa data - a propósito, NINO, Carlos S. Kant versus Hegel, otra vez. La Política: revista de estudios sobre el Estado y la sociedad. 1996, Numero 1. Barcelona; Paidós, 1996.
} 
rais e comunitários, afirmando que ambas as referências hão de estar presentes na sociedade ocidental contemporânea ${ }^{6}$.

Por estas razões, o seguinte exame dos modelos, acima mencionados, pretende colocar em relevo o modo de tratamento dispensado à Democracia e à Constituição, atentando para as contradições resultantes da concepção de sujeito vigente entre liberais e comunitários e observando a crítica efetuada pela proposta de uma política deliberativa baseada exatamente na tomada do sujeito como ponto de partida.

\section{1 - Democracia e Constituição segundo o Modelo Liberal: indivíduo e garantia}

A perspectiva liberal assinala o indivíduo como "valor primário e referencial da sociedade humana" (BONAVIDES, 2003, 615). Esta prioridade é decorrente da noção individualista da liberdade, segundo a qual todo indivíduo é capaz de possuir uma concepção válida sobre a vida digna e está legitimado a procurar efetuá-la, independente de obstáculo alheio. Ao conceber o pluralismo, a partir desta ótica, o pensamento liberal encara como prioridade a liberdade privada e a escolha do plano racional de vida, supondo os indivíduos livres como agentes no processo de possibilidades da vida social. A noção de sujeito emerge na síntese de que, em rigor, todas as expectativas são legítimas ante a capacidade de autodeterminação moral dos indivíduos. Deste modo, há afirmação de uma metodologia que implica um ponto de vista moral mínimo, desautorizando o relativismo quanto à associação política. A suposição central é de que, diante do pluralismo dos projetos pessoais de vida, sujeitos racionais livres e iguais relacionamse em concordância a princípios passíveis de aceitação geral, sendo-Ihes possível o estabelecimento de ajustes normativos válidos.

0 pensamento liberal configura o modelo Constituição-Garantia (CITTADINO, 2000.p.146), isto é, a compreensão da ordem jurídica fundada na legitimação constitucional como atividade de preservação da autonomia privada frente à deliberação pública em um sistema em que é possível saber-se qual indivíduo possui qual direito em situações particulares. Este postulado decorre da noção que afirma a inalienabilidade dos direitos básicos dos indivíduos, designados como direitos subjetivos. Em síntese, a constituição se relaciona com a democracia, ao limitar o processo público de delibera-

\footnotetext{
${ }^{6}$ Cittadino fornece uma apresentação ampla do debate utilizando as designações Liberais (J ohn Rawls, Charles Larmore e Ronald Dworkin), Comunitários (Charles Taylor, Bruce Ackerman e Michael Walzer) e Crítico-Deliberativos (cujo pensador mencionado é J ürgen Habermas). CITTADINO, Gisele. Pluralismo, direito e justiça distributiva: el ementos da filosofia constitucional contemporânea. 2 ed. Rio de J aneiro: Lumen J uris, 2000. 1-2.
} 
ção às definições que todos poderiam subscrever, já que nenhuma concepção individual sobre 0 bem e a vida digna pode ser sobreposta às demais e para que todos possam buscar suas realizações pessoais. Pensar, assim, a Constituição supõe compromisso com a elevação dos direitos fundamentais, acima de todas as concepções de bem e tratá-la como superposição de normas e princípios dotados de uma qualidade deontológica.

A política democrática, na esteira da noção de sujeito e da compreensão de direitos como limites da deliberação pública, supõe um modelo estritamente procedimental. Com efeito, se a sociedade democrática é uma associação de indivíduos dotados de uma noção quanto à vida boa e um plano de vida para alcançá-la; se a função da sociedade consiste em possibilitar este plano, seguindo um princípio de igualdade, sem que se possa dizer existir um único plano superior aos demais; 0 único elemento fundamental é o modo de decisão. Respeitados critérios de igualdade de condições para a disputa, a realização democrática consiste nos resultados das opções entre indivíduos em certames eleitorais nos quais alguns alcançarão sucesso. Os alcances da política estão subordinados às condições de legitimidade da investidura, através da vontade dos votantes, bem como das condições de validade jurídica das ações dos eleitos - em ambas as condições por meio do controle judicial de constitucionalidade.

É preciso observar o modo peculiar como o modelo liberal opera as implicações da dificuldade contramajoritária. Em linhas gerais, esta dificuldade está assentada no problema relativo à legitimidade de juizes em invalidar regras construídas pelo legislador em uma democracia - a questão central refere-se a que juizes não são eleitos. Há duas propostas liberais para resolver esta dificuldade: a primeira proposta subordina o controle de constitucionalidade ao espírito e valores diluídos na população (o ethos democrático). É designado monismo constitucional. Trata-se da compreensão de que governo eleito livremente é governo ilimitado pela democracia. Não há maior autoridade que a da maioria parlamentar, e o Poder Judiciário só intervém, legitimamente, onde houver falha no procedimento que a apura; uma segunda posição sustenta a subordinação da democracia aos direitos fundamentais. Trata-se do fundacionalismo de direitos, que afirma os direitos como antecedentes às decisões do corpo político: o efetivo reconhecimento destes direitos no discurso de aplicação configura a correta interpretação da constituição em um Estado de Direito. Esta perspectiva não nega a dificuldade contramajoritária, mas a resolve mediante a noção de que a democracia não é um valor supremo, sendo subordinada aos direitos fundamentais. Nesta senda, a falta de representatividade dos juizes é compensada por sua função mediadora entre democracia e direitos. Sob este modelo, o povo, diretamente ou representado, não tem autoridade para suplantar direitos fundamentais. Há compromisso com a democracia, mas primordialmente com os direitos fundamentais, pois o povo não é uma entidade constante. 


\section{2 - 0 Modelo Comunitário: democracia como participação e Constituição- projeto}

Enquanto o modelo liberal supõe uma natureza obrigatória nos direitos fundamentais e propõe a Constituição como garantia de sujeitos individuais frente às possibilidades da deliberação pública, o pensamento comunitário insiste na matriz social da própria liberdade individual, enfatizando a comunidade histórica que a valoriza e sustenta a ponto de elevar os direitos que lhe são inerentes à qualidade da lei maior. Na perspectiva comunitária, o modelo constitucional é possível pela autodeterminação política em torno de ideais. A realização da democracia constitucional é real, enquanto atitude de subjetividades participativas, capazes de fazer do processo democrático uma forma peculiar de propiciar entendimentos éticos que sintetizem na Constituição um projeto de destino compartilhado. Importa, neste sentido, verificar duas formulações comunitárias que contraditam a concepção individualista do sujeito e a concepção centralista da constituição7.

\subsection{1 - Charles Taylor e a crítica ao Individualismo Metodológico}

Com o intuito de demonstrar a insuficiência do postulado individualista, Charles Taylor (1991) discute a possibilidade da experiência democrática como decorrência de uma prática genuinamente comum. Trata-se de algo diverso de outras coisas cuja promoção ocorre coletivamente; por exemplo, os bens a que a economia do bem-estar social classifica como bens públicos - Defesa Nacional, Corpo de Bombeiros, Proteção contra enchentes etc. São bens que nenhum indivíduo forma e mantém sozinho. Mas são apenas bens convergentes, eis que 0 fato de serem promovidos coletivamente, apenas demonstra o modo como são construídos e não aquilo que faz deles um bem social. A segurança que proporcionam será a segurança para este indivíduo, aquele e aqueloutro. Se, hipoteticamente, um único indivíduo os promovesse para si mesmo, estaria obtendo o mesmo valor que todos obtêm na forma coletiva da promoção social.

Esta análise instrui a concepção das repúblicas no sentido de que elas têm como algo essencial a animação que advém do sentido de um bem comum imediatamente partilhado. A nossa dívida com uma municipalidade que proporciona o serviço de proteção contra incêndios, não supera a feição de um auto-interesse consciente, convergente com os demais munícipes. $\mathrm{M}$ as o vínculo solidário com os concidadãos em uma república está assentado

\footnotetext{
7 "A retórica do liberalismo limita nossa compreensão dos próprios hábitos do coração e não nos proporciona via alguma para formular as convicções que nos mantêm juntos como pessoas e que unem as pessoas em uma comunidade (...) também explica nossa dependência radical (brilhantemente profetizada no Leviatã de Hobbes) do Estado central". WALZER, Michael. La crítica comunitarista del liberalismo. La Política: revista de estudios sobre el Estado y la sociedad. Primer semestre 1996. Numero 1. Barcelona: Paidós, 1996., 51. (tradução nossa)
} 
em uma compreensão de destino compartilhado onde o que tem valor é exatamente este compartilhar. Por isso, um regime republicano exige uma ontologia não atomista/individualista e resistente ao senso comum por ela impregnado. Esta ontologia requer o exame das questões de identidade e comunidade, visando ao ingresso nas diferentes possibilidades de verificar-se o lugar das identidades-nós no âmbito de bens imediatamente comuns, para além das identidades-eu, resumidas à pretensão de bens meramente convergentes. É neste contexto de análise que se pode superar a concepção instrumental de atividade coletiva para dar lugar à concepção de ação comum, indispensável à lógica republicanå.

O que de fato está em disputa, assevera Taylor, são os alicerces da tradição cívico-humanista, cuja tese básica tem como condição essencial para uma sociedade livre (não despótica) a identificação patriótica profunda entre os cidadãos. Esta tese conta com distintos argumentos favoráveis, mas que, de uma ou outra maneira, sintetizam uma defesa da liberdade. Pode-se observar que o conceito de liberdade que propõe extravasa os limites da chamada liberdade negativa, reivindicando uma liberdade participativa do cidadão ativamente participante dos temas públicos, sobre o qual a disciplina, que seria imposta pelo medo sob o despotismo, há de ser auto-imposta na ausência dele. Apenas a identificação comunitária consigna a base de empolgação imprescindível a este mister. Pode-se acrescentar, ainda, que um regime de liberdade fundado na participação chama os cidadãos a promoverem os bens que o despotismo promoveria por eles. Neste sentido:

A república cidadã há de ser valorada não só como garantia da utilidade geral ou dos direitos individuais (...) também a valoramos porque, em geral, cremos que a forma de vida na qual os homens se governam a si mesmos e decidem seu próprio destino através da deliberação comum é melhor que aquela em que vivem como súditos, inclusive de um despotismo ilustrado (TAYLOR, 1996. 79).

0 aspecto essencial reside na compreensão de que a solidariedade republicana baseia-se na liberdade, pois possibilita a motivação para a disciplina auto-imposta. Pode-se afirmar, também, que ela é essencial a um regime livre, pois requer dos cidadãos atitudes das quais súditos pretendem distância - regimes livres são sempre bastante trabalhosos. 0 que Taylor sustenta é não haver realidade democrática sem projeto comum de vida boa. Daí porque sua afirmação de que 0 atomismo, que se pauta nas concepções individuais de bem, como fundamento explicativo da democracia, é uma quimera. Aliás, exclama:

\footnotetext{
${ }^{8}$ Neste sentido ver PEDRANA, Yamila. Algunos problemas de la reintrodución de los temas de la vida buena en la propuesta de Charles Taylor. Revista de Filosofia y Teoria Política. Facultad de Humanidades y Ciencias de la Educación. Universidad Nacional de La Plata. Departamento de Filosofia. Argentina. 1996, 239.
} 
0 puro auto-interesse esclarecido nunca moverá um número suficiente de pessoas com força bastante para constituir uma real ameaça a déspotas e putschistas potenciais. Do mesmo modo, não haverá um número suficiente de pessoas movidas pelo princípio universal, não misturado com identificações particulares, cidadãos morais da cosmópolis, estóicos ou kantianos, capazes de deter os ataques destes vilões (TAYLOR, 1996. 213).

Daí a crítica ao liberalismo procedimental e à sua vedação à primazia do bem sobre 0 direito. Nesta perspectiva as aspirações e demandas mais valoradas socialmente, só poderiam resultar de uma promoção de aspirações e demandas operadas por seus componentes individuais. 0 autor canadense afirma que este ponto de vista teórico é irrealista, pois numa convivência democrática há sempre uma concepção de bem socialmente sancionada que induz o direito. Neste sentido, homens e mulheres identificam-se numa sociedade particular no pressuosto de que as instituições políticas e jurídicas a que devem obediência, são uma expressão de si mesmos. Trata-se da virtude de um patriotismo de tradição humanista e cívica, segundo o qual a disciplina não é imposta, externamente, como coerção, mas auto-imposta no exercício da diversidade mantida por ideais comuns motivadores, os quais redundam em participação.

0 objetivo consiste em realçar uma distinção errônea que separa questões que são para mim e para você de um lado e aquelas que são para nós, do outro. Este aspecto é essencial em toda atividade social, pois é característico do ser humano em suas expressões desde 0 afeto até a identidade política, desenvolver-se mediante atos de intimidade, nos quais não há agregação de expressões individuais, mas empreendimentos dialógicos, que tornam o que é para um e outro em algo para eles. Em termos impessoais, institucionais, esta temática ganha relevo, na medida em que a transposição do para mim/para você ao para nós, significa a passagem de um espaço íntimo para o espaço público, a qual se manifesta concretamente em relação aos bens sociais. Há bens que têm valor para mim e para você; mas há bens que têm valor somente para nós, porque exatamente o seu ser para nós os constitui como bem valorado.

\subsection{2 - A Teoria Dualista da Democracia e da Constituição}

À luz dos argumentos contrários à noção de sujeito, desenvolvida a partir do individualismo metodológico, pode-se verificar os desdobramentos das formulações comunitárias sobre as relações entre democracia e constituição. É de salientar, que o pensamento comunitário não se propõe a resolver a dificuldade contramajoritária (2.1), mas na verdade, se propõe a dissolvê-la, afirmando que o controle de constitucionalidade é da essência da prática democrática e que as visões liberais (monismo e fundacionalismo) são incapazes de perceber esta realidade, porque cometem um erro fatal, ao pensar a constituição - a percebem em termos centralistas.

Abordar este problema requer uma pergunta básica segundo a teoria constitucional de Bruce Ackerman (1999): onde se faz a política? Uma resposta 
imediata (fácil) dirá: na capital; onde o rei e a gente importante estão. Esta idéia perdura na cultura política eurocêntrica. 0 rei foi mandado embora, mas a vida política continua restrita ao centro, e a democracia se restringe à possibilidade de a plebe eleger alguns indivíduos em períodos destacados, para que estes manejem a política cotidianamente. Este panorama é que facilita a resposta fácil. E é somente sob seus limites que o controle judicial de constitucionalidade parece uma ameaça à política, quando é apenas ameaça à política-de-elites. Para além da resposta fácil, reivindica o autor norte-americano, é preciso questionar: devemos aceitar a política como matéria apenas para o centro? Se a resposta for negativa, como se relacionam o controle de constitucionalidade e o domínio do político?

Existe apenas um momento na perspectiva centralista em que as massas participam - quando elegem uns políticos e não outros, "escolhendo entre os cortesãos quem Ihe representará perante o Rei (morto)" (ACKERM AN, $1999,147)$. Ainda que a intenção seja questionar este modelo, examine-se primeiro o seguinte: não há nos marcos centralistas meios para maior participação da periferia? Como neste quadro se deve apreciar o controle judicial de constitucionalidade? Várias respostas têm sido formuladas na ponta do debate constitucional nos EUA e Alemanha. A simples lógica apresenta duas respostas: em primeiro lugar, os políticos não podem, crivelmente, pretender falar em nome do povo se conduzem a eleição à moda totalitária como nos Estados do leste europeu, nas comunidades teocráticomilitaristas da Ásia e África e mesmo no Brasil entre 1964/82 com as eleições bipartidárias. Em segundo lugar, a representação deve estar baseada em um processo no qual o povo, na periferia, possa efetuar uma eleição livre e justa entre alternativas genuínas. Assim, surge 0 argumento institucional: é muito perigoso permitir aos próprios políticos dirigirem a eleição, pois suas atitudes perante rivais transformarão a eleição numa paródia. Aqui entram os juízes, ao promoverem uma salvaguarda institucional às ambições dos atuais governantes, pois, já que possuem independência de vitórias eleitorais, podem resistir a quaisquer esforços manipuladores ou fraudulentos sobre a eleição.

Até aqui, o modelo de democracia foi o centralista - o povo só participa na eleição. Fora da eleição, a Democracia Constitucional está reduzida aos círculos elitistas do centro, configurando um único caminho legislativo, qual seja 0 ato parlamentar que representa a vontade popular. Um modelo centralista renovado, no máximo aspira purificar o processo eleitoral, de modo que reforce a representação popular. Assim, estabelecendo-se que juízes garantam a eqüidade fundamental do processo, não sobra espaço para perguntas perturbadoras acerca de até que ponto poucos políticos, na capital, representam adequadamente o povo, ou, então, até onde podem ir os juizes em termos de políticas sociais. Contraditando esta perspectiva centralista, a Teoria Dualista visa problematizar a representação ordinária, sem negar-Ihe legitimidade. Esta perspectiva reconhece que há momentos em que o povo age com mais intensidade e consistência acerca de si pró- 
prio do que naqueles de eleições, nos quais apenas escolhe entre políticos adversários. Nesses, o povo, na mobilização, vai além da opção entre políticos e encontra a situação em que está dando uma ordem aos mesmos. Estes são os momentos constitucionais.

Uma constituição dualista possui dois caminhos legislativos: o normal, no qual os políticos eleitos democraticamente estão legitimados a promover leis que servem ao interesse público (momentos correntes ou de política normal); o outro, é o sistema de legislação superior, composto de plebiscitos e outros procedimentos deliberativos mediante os quais um movimento da política constitucional obtém o consenso profundo, amplo e contundente do povo. Uma proposição constitucional que sobreviva a este teste conta com a legitimidade essencial: o povo a determinou. Após esta determinação, entram os juízes em cena, pois é preciso efetividade institucional para assegurar que a política normal desenvolvida pelos políticos do centro não solape a seriedade da determinação popular. Ao invés de acomodarem-se no cotidiano da política normal, deverão os políticos realizar a grande tarefa imposta pelo sistema de legislação superior - fomentar um momento constitucional, isto é, possibilitar um processo de convencimento em larga escala, apto a demonstrar ampla, profunda e contundentemente que o povo mudou de opinião. Com a habilitação de juízes para este tipo de atuação, a constituição dualista não está abolindo o político, mas reorganizando-o.

Por entender que seria uma ilusão supor que as transformações essenciais, em termos de filosofia pública, são obras de processos elitizados, de interpretação constitucional, independentes da luta popular sobre legislação superior, afirma Ackerman que o dualismo, apresenta-se como modo capaz de conter as demandas dos políticos de falarem em nome do povo sobre legislação superior. 0 autor esclarece que um drama contemporâneo especial é o distanciamento do governo da soberania popular. Um governo pelo povo é algo bastante diferente do amálgama de políticos e burocratas triunfantes na eleição. Ainda que não haja remédio eficaz contra esta situação, o dualismo invoca o poder da magistratura em afirmar a força da memória histórica, ao cristalizar que houve tempos em que uma cidadania mobilizada lutou pelo assentamento de princípios de governo e estes não podem ser fulminados por atores momentâneos nos círculos administrativos e legislativos. Quando a Corte invalida uma legislação produzida pelo Parlamento, simplesmente está informando ao povo que algo importante está ocorrendo nos bastidores do Poder Político, notadamente que os mandatários estão governando em colisão com os postulados essenciais das anteriores mobilizações populares e se autoproclamando formuladores de princípios fundamentais em lugar do povo. Para este fim, questiona Ackerman, não deveriam os políticos fazer algo além de ganhar uma última eleição?

A Constituição dualista apresenta uma solução dialógica a este problema. Mais do que o discurso fácil de um mandato do povo, os administradores públicos e os parlamentares devem auferir autoridade constitucional para estabelecer proposições de um direito superior, como fruto de uma grande 
persuasão pública apta a legitimar mudanças de princípios. Se isto está alcançando bom funcionamento, o esforço judicial por síntese intergeracional exalta a atitude dos cidadãos contemporâneos em expressar uma vontade constitucional. Ao buscar os significados constitucionais do passado e darIhes importância em casos concretos contemporâneos, os tribunais fornecem um espelho para as gerações atuais. Se a imagem refletida não Ihes agrada, então hão de empenhar-se para mudar o que, na tradição, deixou de ser aceitável e participar na construção de novos significados constitucionais.

A Constituição e a Democracia são dualistas, portanto, conforme protegem a autonomia privada e os direitos individuais em momentos correntes, bem como preservam à comunidade política a titularidade quanto à afirmação de sua própria identidade em momentos constitucionais. Daí, ser a Constituição primeiro democrática e depois, protetora de direitos, porque ela não dita direitos que o povo tem de anotar - ele é a fonte dos direitos! Imaginar a inalterabilidade dos direitos fundamentais seria imaginar que o processo histórico é estático. Uma vida republicana não cai do céu; só existe no mundo habitado de cultura, no qual o presente descobre sua voz no diálogo com o passado. Por esta razão Ackerman frisa que a imutabilidade dos direitos fundamentais não pode ser defendida em termos de que são eles os padrões morais mais elevados da comunidade política, fixados definitivamente. Em toda experiência constitucional se encontra sempre o espírito desta constituição e desta declaração de direitos, cujo fito consiste em garantir procedimentos justos para resolução dos conflitos, mas, sobretudo, garantir aos movimentos populares a discussão e decisão políticas sobre o futuro pretendido.

0 essencial é que os cidadãos, permanentemente, podem interpretar passado, presente e definirem seu futuro, redefinindo-se enquanto povo. Uma comunidade que altera seus valores compartilhados pode alterar a constituição, criar outra ou determinar novos marcos de interpretação. Trata-se da capacidade de autodeterminação da comunidade, da disposição republicana em "alterar legitimamente seus compromissos políticos e normativos"(ACKERM AN, 1999. p. 147). A democracia dualista proporciona ao indivíduo a saga de seu projeto, mas garante que, em momentos políticos decisivos, os cidadãos em conjunto possam projetar o destino a ser compartilhado.

\section{3 - 0 modelo da política deliberativa proposto por Habermas}

Habermas (2002) efetua o que designa tipificação ideal dos pensamentos liberal e comunitário, a fim de expor suas diferenças relativamente à natureza do processo político democrático. As conseqüências destas diferenças são visualizadas nas noções de cidadão do Estado e de Direito em si mesmo. Para o liberalismo, observa, a democracia constitucional programa o Estado para a garantia da disputa de interesses individuais na sociedade. Assim 
os direitos políticos constituem direitos subjetivos que validam a presença na disputa e a ordem jurídica, neste sentido, funda-se como esquema racional para aplicação do poder normativo e coercitivo a situações concretas. Já na formulação comunitária a cidadania emerge de um fenômeno mais abrangente que 0 interesse individual e consigna a proposta de uma política constitutiva, reflexo de um determinado contexto de vida ético com raízes mais sólidas que o dinheiro ou poder administrativo - a solidariedade que eleva os direitos subjetivos a uma ordem objetiva que impõe convívio como livres e iguais. Como desdobramento essencial desta diferenciação resulta a observação de que o poder político democrático é disputado na perspectiva liberal por agentes portadores de pretensões de poder que buscam sucesso político como em uma atitude de mercado; e que na perspectiva comunitária não há designação de um modelo de disputa fundado no sucesso da obtenção de poder político por parte de indivíduos que alcançam autorização, mas sim que recebem vinculação - a investidura no poder político supõe o quê fazer.

Habermas localiza as debilidades de liberais e comunitários em um mesmo aspecto, ainda que haja manifestação diferente em cada caso - a presença de uma noção de sujeito totalizante $(2002,280)$. Seja no indivíduo racional interessado, cuja desenvoltura segue o esquema do mercado, seja no entendimento ético possível na identidade coletiva, há 0 que 0 autor alemão designa incapacidade para apreender a força legitimadora da opinião e da vontade. Mesmo que o pensamento comunitário tenha uma vantagem sobre a perspectiva do sujeito à feição do mercado (são duras as críticas de Habermas ao que designa homem pelo sucesso próprio [1997]), acaba incorrendo em erro exatamente por efetuar uma apreensão estritamente ética dos discursos políticos.

A partir das análises apontadas, a formulação de uma política deliberativa, proposta por Habermas, procura conceber a legitimação constitucional da prática democrática no bojo de comunicações sem sujeito, onde seja visualizado o amálgama da forma parlamentar de aconselhamento e decisão fundada na ação comunicativa da opinião pública de cunho político. Neste sentido:

(...) Estas comunicações sem sujeito, internas e externas às corporações políticas e programadas para tomar decisões, formam arenas nas quais pode ocorrer a formação mais ou menos racional da opinião e da vontade acerca de temas relevantes para o todo social (...) a formação de opinião que se dá de maneira informal desemboca em decisões eletivas institucionalizadas e em resoluções legislativas pelas quais o poder criado por via comunicativa é transformado em poder administrativamente aplicável (HABERM AS, 2002, 282).

Tendo analisado características centrais das proposições atuais acerca dos modelos normativos de Constituição e Democracia, torna-se oportuno lançar as bases de uma possível relação das mesmas com os modelos de Estado desenvolvidos no item 1 do presente trabalho. 
Com efeito, fora observado que a perspectiva do sujeito atomizado, que inspira o pensamento liberal, conduz à afirmação de um modelo de democracia, que se insere em uma matriz centralista e adstrita à preocupação estritamente procedimental, sob a qual a Constituição se limita à Garantia de que os cidadãos optem pelo rodízio das elites que exercem o poder político e que este esteja limitado pelos direitos inalienáveis. Nota-se, portanto, a relação com o Estado Liberal de Direito (1.1). Já a perspectiva comunitária, de par com a noção do sujeito-em-relação, isto é, para além do indivíduo interessado e portador de uma subjetividade intrinsecamente fundada nos limites da vontade particular, cristaliza um modelo de democracia decorrente de uma dimensão participativa da subjetividade, que se desenvolve no seio de uma identidade constituída por valores e ideais comuns. Resulta que a Constituição figura como Projeto. E, neste caso, vislumbra-se a relação com o Estado Social de Direito (1.2), uma vez que não se cogita de mera garantia, mas de vinculação ao cumprimento dos objetivos de um destino socialmente compartilhado.

Dentre as características assinaladas acerca do Estado Democrático de Direito (1.3), observou-se a realização de transformações significativas relativamente aos modelos liberal e social de Estado, as quais compõem uma nova grade de idéias relativamente aos problemas da Democracia e da Constituição, pensando-os sob o ponto de vista da eficácia para a participação política e para o exercício dos direitos. Pode-se verificar o mesmo sentido nas formulações de Habermas ${ }^{9}$ (2.3), quando localiza os limites das formulações liberais, impregnadas de um sentido competitivo, cujo marco é o mercado, e quando critica o peso excessivo atribuído à categoria da solidariedade social como postulada pelo modelo comunitário. Não se trata, exatamente, de um resgate conceitual dos valores fundamentais de liberdade e igualdade, mas, sobretudo, da preocupação quanto aos mecanismos jurídicos institucionalizados aptos a efetivá-los na vida cotidiana.

Este panorama, que resgatou o pano de fundo moderno e o reflexo contemporâneo das controvérsias relativas aos temas da Constituição e Democracia, indica a urgência da análise da teoria constitucional produzida por Hegel. 0 item seguinte propõe um estudo da organicidade constitucional hegeliana, que permite evidenciar a vinculação dos postulados fundamentais do comunitarismo com a mesma, notadamente no que concerne às formulações relativas ao republicanismo patriótico e à validação das normas, segundo a aceitação da comunidade histórica, bem como pela idéia da ordem a ser compreendida como compromisso em torno de ideais. Ora,

\footnotetext{
${ }^{9}$ I nteressante observação sobre o pensamento de Habermas: "Sua filosofia defendeu um marxismo teórico, desenvolvido na Escola de Frankfurt, como discípulo de Adorno (...). Hoje se apresenta como uma formulação que tem pontes entre o liberalismo de livre mercado e o Estado Social". ELOSEGUI, Maria. La inclusión del otro. Habermas y Rawls ante las sociedades multiculturales. Revista de Estudios Políticos Nueva É poca. №. 98, 1997. (Tradução N ossa).
} 
é este enlace que permite ao Estado Constitucional ser pensado, a partir da significação de um projeto, mediante o qual sujeitos portadores de uma identidade autônoma configuram a sociedade que possibilita 0 desenvolvimento desta própria autonomia. Conforme será visto, o ordenamento constitucional, sob esta perspectiva, simboliza uma identidade política e não, um standard diretivo apriorístico. Trata-se de um esforço coletivo, de uma mobilização que sintetiza passado e presente em favor de um certo futuro, estabelecendo uma conexão intrínseca entre constituição e transformação (ACKERM AN, 1999. p. 165).

\section{3 - A organicidade constitucional hegeliana}

0 tema da Constituição aparece ao longo da produção filosófica de Hegel que entende 0 desenvolvimento histórico dos povos como a passagem de um tipo de Constituição para outro. Conforme ele pensa, a Constituição é uma estrutura objetiva de um organismo político e não somente um documento escrito. Ela é mais que uma lei suprema donde se derivam outras que regulam os poderes no âmbito do Estado: É o conjunto de estruturas que permite a elevação de um povo para ser um Estado. É o princípio de unidade de uma sociedade, dividida em grupos e categorias, com interesses contrapostos.

A Constituição funda a concepção orgânica de Estado que se opõe à visão atomista dos jusnaturalistas. Hegel critica, por exemplo, a concepção do direito privado que pretende explicar o Estado, a partir da propriedade ou do contrato. Pois, se "o constitucionalismo é uma teoria da Constituição como garantia das liberdades individuais: o "constitucionalismo" de Hegel é uma teoria da Constituição como fundamento da unidade estatal" (BOBBIO, 1991, p. 110). Ele entende, também, que um Estado constitucional não é um Estado absolutista, pois garante direitos fundamentais de liberdade, e a diferenciação dos três poderes.

No entender de N. Bobbio, há em Hegel dois momentos, no tratamento do tema da Constituição: a) Nas obras ético-políticas, anteriores à 1a edição da Enciclopédia e à Filosofia do Direito, o tema da Constituição não se refere ao Direito, no sentido jurídico; b) É na Filosofia do Direito que a Constituição passa a ser o fundamento jurídico do Estado. Porém, a Constituição não é reduzida a uma categoria jurídica, pois ela tem por objetivo a organização da esfera da eticidade. A Constituição é um conceito ético-político, isto é, nasce do "espírito do povo". Não é o produto de uma lei formal, mas uma criação contínua e informal. Entre os dois momentos, há uma convergência hegeliana: a idéia da Constituição, enquanto organização do todo, na diferenciação de suas partes.

A organicidade constitucional hegeliana opõe-se, tanto à visão contratualista e absolutista de Estado, como ao organicismo romântico (MÜLLER, 2004, 
9). A Constituição em Hegel decorre de sua concepção especulativa da vida orgânica que se determina como universal-particular-singular no Estado (Enc, 1995, § 216).

\section{1 - A organização constitucional do Estado}

A organização constitucional do Estado dá-se em dois momentos, a partir da articulação dos interesses privados (organização sócio-jurídica) e dos interesses públicos (organização ético-política).

\subsection{1 - A organização sócio-jurídica constitucional}

A rigor, a concepção do organismo político, enquanto vinculado à perspectiva constitucional da eticidade, já se anuncia desde o § 157 da Filosofia do Direito:

0 conceito desta idéia não é senão enquanto espírito, que tem um saber de si e que é efetivo, pois ele é a objetivação de si-mesmo, o movimento através da forma de seus momentos. Ele é portanto:

A) 0 espírito ético imediato ou natural; - a família. Esta substancialidade passa à perda de sua unidade, à cisão e ao ponto de vista do relativo, e ela é assim

B) sociedade civil, união dos membros enquanto indivíduos-singulares subsistindo por si, em uma universalidade [que é] portanto formal, por meio de suas necessidades, por meio da constituição jurídica (enquanto meio da seguridade das pessoas e da propriedade), e por meio de uma ordem exterior para seus interesses particulares e comuns [.] Este Estado exterior

C) se retoma e se reúne no fim e efetividade do universal substancial e da vida pública a que ele é dedicado, - na constituição do Estado.

Neste parágrafo, Hegel concebe dois momentos da Constituição, uma, dita constituição jurídica, que serve para garantir a segurança das pessoas e da propriedade; a outra, é dita a Constituição do Estado, cujo fim e realidade é a vida pública.

Vejamos aqui, a organização sócio-jurídica constitucional, que corresponde à Constituição jurídica, ora mencionada. Tal Constituição, nos termos do parágrafo 265 da Filosofia do Direito, resulta do conjunto de relações que instituem a família e a sociedade civil, no que estas esferas têm de ético.

Estas instituições formam a Constituição, isto é, a racionalidade desenvolvida e efetuada, no particular, e são, por isto, a base estável do Estado, assim como a confiança e a disposição de espírito dos indivíduos para com este, e [elas são] os pilares da liberdade pública, considerando que nelas a liberdade particular é realizada e racional, [e] que assim, nelas, estão presentes a união da liberdade e da necessidade em-si. 
Este parágrafo deve ser lido em consonância com o § 255, pois as instituições de que se trata são a família e as corporações, instituições que, segundo 0 mencionado $\S 255$, correspondem às raízes éticas do Estado, que nutrem os indivíduos de uma cultura do universal, necessária à vida pública na esfera estatal, principalmente munindo os indivíduos daquela disposição de espírito que o Estado requer, qual seja, o patriotismo.

Há assim, uma correspondência entre a Constituição jurídica que, assegurando as necessidades particulares dos indivíduos, desenvolve neles a confiança no Estado, a ponto de garantir a consciência de que 0 interesse substancial e particular dos cidadãos vê-se contido e preservado no interesse do Estado (FD, § 268). De maneira que, a Constituição política é pressuposta pela Constituição jurídica.

Hegel, já desde o ensaio sobre o Direito Natural, reconhece ao Direito um papel de mediação necessária à superação do caos que se coloca com a atividade humana social, partindo da luta contra as necessidades, na direção de uma vida verdadeiramente ética, conforme expressão de Bourgeois, como vida no e para o povo politicamente organizado (BOURGEOIS, 1986, 328). Nesta esfera da Constituição dita jurídica, Hegel insere o Direito como um momento relativo no todo hierarquizado da eticidade, que tem o papel de afirmar a universalidade dos sujeitos particulares, ou seja, de fazer a mediação, para que se dê o reconhecimento recíproco nas interrelações, que se estabelecem entre as pessoas. Assim, a feição jurídica da propriedade materializa-se em função do reconhecimento social, e não de aspectos meramente formais.

Tendo em conta o escopo do presente trabalho, que se debruça sobre a relação entre os estados no plano internacional, torna-se inviável um exame acurado desta Constituição jurídica, em detrimento da Constituição política que examinaremos a seguir.

\subsection{2 - A organização ético-política constitucional}

0 pressuposto constitucional está dado no espírito do povo que se torna 0 elemento indispensável para propor a organização da Constituição. A partir, disso, Hegel supera uma série de impasses, sobretudo, aquele que dizia respeito à competência de fazer a Constituição.

\section{a) A Constituição, o espírito do povo e a vida orgânica do Estado}

Hegel apresenta uma ordem constitucional do Estado, conforme a estrutura lógico-conceitual, cuja expressão resulta na auto-organização e autodiferenciação do todo ético, conforme a história e a cultura do povo. Por isso a resposta a pergunta: Quem deve fazer a Constituição, encontra na relação dialética entre o espírito do povo e o espírito do tempo o seu sentido. Hegel critica, segundo Bobbio, no que diz respeito à elaboração da 
Constituição, tanto o revolucionarismo daqueles que desejam impor Constituições de fora, bem como o tradicionalismo dos que defendem um Estado estamental, que impede 0 avanço para o Estado da monarquia constitucional.

A Constituição é algo que se desenvolve no tempo, portanto, não é algo extraído da cabeça de um soberano. Daí, a insistência hegeliana que todo o povo tem a Constituição que Ihe é apropriada. Hegel valoriza a história, 0 espírito do povo (Volksgeist) e o espírito do tempo (Zeitgeist). Aquilo que corresponde ao espírito do povo, pode não coincidir com o espírito do tempo e vice-versa. Pois, em determinados períodos históricos, sobretudo em épocas de crise, em que ocorrem as grandes transformações, as acelerações da história, a adequação ao espírito do tempo precede e faz avançar o espírito do povo. Ou seja, na filosofia da história hegeliana, o espírito do povo representa o princípio da continuidade e o espírito do tempo encarna o princípio da mudança (cf. BOBBIO, 1991, 108). A razão hegeliana não se sobrepõe à história, mas também não se limita a justificá-la, daí a dialética entre o espírito do povo e o espírito do tempo.

A Constituição tem uma dimensão formal, enquanto é uma carta de princípios políticos e jurídicos, ou seja, a Constituição-garantia, segundo os liberais. Porém, ela é, ao mesmo tempo, a expressão histórica do "espírito do povo", isto é, a Constituição-projeto, conforme os comunitaristas. "O Estado, enquanto espírito de um povo é, ao mesmo tempo, a lei que penetra todas as situações da vida desse povo, os costumes e a consciência dos seus membros; assim a constituição de um determinado povo depende em geral, da natureza e da cultura da autoconsciência desse mesmo povo. É nesta consciência que reside sua liberdade subjetiva e, por conseguinte, a realidade da constituição" (FD, § 274). Por isso, Hegel opõe-se, veementemente, à pretensão de querer outorgar ao povo uma Constituição de modo a priori, pois isto seria ignorar o momento histórico e a cultura específica de cada povo.

A concepção hegeliana da Constituição descreve a maneira como uma totalidade ética - um povo - se organiza. Entretanto, Hegel não se limita a isso, trata de compreender especulativamente 0 presente e 0 real. Ao passo que as demais teorias precedentes percebiam a Constituição política de um povo como sendo um ato inaugural, fruto de uma inovação que deixava de considerar a história ética anterior.

O parágrafo 271 da Filosofia do Direito introduz o tema da Constituição sob seu aspecto puramente interior. A Constituição política (die politische Verfassung) tem uma função fundamental que é "a organização do Estado e o processo de sua vida orgânica em relação a si mesmo" (FD, § 271). A Constituição é, portanto, um organismo que se diferencia em muitas partes e, simultaneamente, as conserva unidas a si mesma. Eis aí a idealidade da Constituição: um organismo que mantém a unidade das partes. A diferenciação do conceito, mantém nas partes 0 todo. Esse movimento especulativo de diferenciação e unidade das partes no todo é o sentido especulativo da 
própria Constituição. Esta se manifesta no Estado em seus momentos diferenciados como universal (poder legislativo), particular (poder executivo) e singular (poder do príncipe). Ora, essa dimensão lógico-política dos poderes permite superar a interpretação do "entendimento abstrato" que os compreende, enquanto separados. Ao contrário, o sentido especulativo constitucional preserva-Ihes o caráter orgânico de unidade em suas diferenças no interior do Estado (RAMOS, 2000, p. 233).

\section{b) A Constituição segundo a lógica do conceito}

0 conceito contém para Hegel "os momentos da universalidade, enquanto livre igualdade consigo mesma em sua determinidade; da particularidade, da determinidade em que permanece 0 universal inalteradamente igual a si mesmo; e da singularidade, enquanto reflexão-em-si das determinidades da universalidade e da particularidade". Aqui, encontra-se a fundamentação lógica do conceito da Constituição, pois "cada momento do conceito é, ele mesmo, o conceito todo" (Enc, § 163). Tendo isto pressuposto, Hegel analisa a determinação da Constituição em seus três poderes, como sendo a diferenciação do conceito em três momentos, pondo-se como unidade inseparável. Cada um dos poderes tem a sua especificidade e o todo, isto é, a relação com os outros poderes.

Os poderes estatais são particulares e, ao mesmo tempo, contém em si 0 todo do Estado. A Constituição é racional, na medida em que é capaz de diferenciar e determinar sua atividade, através dos três poderes estatais, segundo o modo do conceito. Ou seja, o conceito é cada um dos poderes diferenciados e mantidos numa totalidade orgânica, permanecendo na sua idealidade "um todo individual" ( FD, § 272). Por isso, Hegel opõe-se à teoria liberal da separação dos poderes, embora, esta contenha um momento essencial do conceito que é a diferença. Esta, porém, é apreendida pelo entendimento abstrato, resultando uma autonomia absoluta dos poderes, uma unilateralidade que os impede de relacionar-se mutuamente, senão limitar-se reciprocamente. Ao contrário, a teoria especulativa do conceito garante a superação da teoria da separação liberal dos poderes (FD, § 272, Obs.).

Em seguida, temos no parágrafo 273 , a exposição silogística dos três poderes, começando pelo universal, depois pelo particular e, enfim, o singular. Hegel desenvolve, no poder do príncipe, como se opera o silogismo do conceito constitucional: 0 poder do príncipe contém em si mesmo os três momentos da totalidade: a) o momento da universalidade, fazendo referência à Constituição e às leis; b) o momento da particularidade que se põe em relação com o universal, através da consulta; c) enfim, o momento da singularidade que é o da decisão final, como um ato de autodeterminação, englobando todos os outros momentos (FD, § 275). Percebe-se que Hegel enuncia uma ordem silogística dos poderes no $\S 273$ (U-P-S) e depois, ao analisar cada um destes, inverte a ordem que acabara de enunciar, começando pelo "poder do príncipe" (§ 275 - singular) para terminar com o "poder legislativo" (§ 298 - universal). A significação lógica desta inver- 
são é, segundo Rosenfield (1991, 234), o vínculo íntimo entre ambos. Segundo, Labarrière-Jarczyk (1989), o que importa é o movimento silogístico entre os poderes, independentemente, donde se possa começar.

Cabe destacar que o poder do príncipe não corresponde em nada à autoridade da monarquia absolutista, como o deixa ver o § 273 FD, "o desenvolvimento do Estado até a monarquia constitucional é uma obra do mundo moderno". Hegel vê, como necessário, contemplar na idéia do Estado constitucional o que há de mais característico na era moderna: os princípios da subjetividade e da liberdade. Assim, as instituições objetivas do Estado devem expressar aqueles princípios, diz Hegel:

Ora, na verdade, a subjetividade não é senão enquanto sujeito, a personalidade não é senão enquanto pessoa; e, na constituição que prosperou até a racionalidade real, cada um dos três momentos do conceito tem sua configuração separada, efetiva por si. Por conseguinte, este momento do todo que decide, absolutamente, não é a individualidade em geral, ele é, ao contrário, um indivíduo, o monarca (FD, § 279).

A vontade do príncipe é essencial na ordem constitucional hegeliana, mas esta manifestação - este eu quero - não pode ser interpretada como um arbitrário desejo individual. Na monarquia que corresponde à modernidade, 0 aspecto objetivo pertence unicamente à lei e a função do monarca consiste meramente em imprimir-Ihe o subjetivo "por minha vontade" (FD, § 279 Obs.).

No poder governamental, o silogismo do conceito dá-se assim: 0 governo realiza a subsunção do particular sob o universal assim como a particularização deste universal. Ele aplica as decisões do poder do príncipe (FD, § 287). Assim, o poder governamental (particular) é um termo médio que exige, por sua vez, duas mediações, a do poder do príncipe (singular) e a do poder legislativo (universal).

Hegel procede à análise do poder executivo ou governamental, cuja tarefa, na ordem constitucional é a de limitar o enorme poder irracional da sociedade civil, já apontado desde o artigo sobre o Direito Natural, o Sistema da Vida Ética e a Real Filosofia. Este poder tem uma função mediadora ou intermediária, posto que é concebido como um estado universal (Stand) da sociedade civil e, ao mesmo tempo, um instrumento do Estado, constituindo um nexo entre 0 particularismo da sociedade e 0 universalismo estatal. Esta articulação do particular com o universal, efetuada pela burocracia, ocupando a posição intermediária, é independente das atividades econômicas e interesses privados da sociedade civil, pois o Estado a mantém. Por isso, tem sua atividade motivada pelos interesses universais (cf. FD, $\S 205$ ). Primeiramente, cabe à atividade governamental, a subsunção do particular no universal; depois, realizar a particularização deste universal (ROSENFIELD, 1983, p. 244).

0 poder legislativo é ele mesmo uma parte da Constituição e a pressupõe (FD, § 298). A relação entre a Constituição e o legislativo é um movimento 
de mútua pressuposição, pois a Constituição é o todo que põe o poder legislativo e ela, por sua vez, é posta por ele. O legislativo é um poder encarregado de cuidar da Constituição e de elaborar novas leis que respondam às necessidades da família e da sociedade civil e do Estado. Por isso, ele tem a responsabilidade da universalidade da vida do Estado. 0 poder legislativo é o espaço em que participam o poder do príncipe (singular) e da administração-governamental (particular), isto é, nele convergem os dois poderes. Daí, ser um poder constitucional encarregado de zelar pela universalidade das necessidades estatais (ROSENFIELD, 1983, 248).

Hegel, embora fascinado pelo modelo da democracia grega, vai adequá-la aos tempos modernos. Assim, é inevitável que a participação dos cidadãos aconteça de maneira mediada por uma representação, e não mais de maneira direta, como na experiência democrática da antiguidade. Esta representação acontece mediante a Assembléia dos estados, que deve refletir a articulação e agregação dos interesses da sociedade civil. Portanto, nela estão representados o estado do empreendimento e o estado substancial (FD, § 203 e § 204). A atividade legislativa assegura que a universalidade empírica dos cidadãos venha a estruturar-se organicamente através dos estados, corporações e comunas.

Visto como um órgão de mediação, o poder legislativo se encontra entre 0 governo, por um lado, e a nação, dividida em sua particularidade (povo e associações), por outro; enquanto, termo médio, impede, tanto 0 isolamento extremo do poder nas mãos da coroa, como o isolamento dos interesses privados das pessoas, associações e corporações. Desta mediação resulta, principalmente, que o Estado se efetiva na consciência do povo, e como este passa a participar da vida pública. Esta participação, deverá ocorrer na forma de associações, ou articulações dos estados, e não sob a forma de uma representação individual direta, atomizada. Assim, "o poder legislativo medeia as relações políticas, à medida que a participação orgânica dos cidadãos nos assuntos políticos aí encontra um lugar de realização" (ROSENFIELD, 1983, 251).

Enfim, a análise da Constituição segundo a lógica do conceito, mostra que a relação entre os diferentes poderes é fundamental para compreender a organização política hegeliana. "A Constituição é, essencialmente, um sistema de mediação" (FD, § 302, adição), que através do silogismo dos três poderes mantém a organicidade do Estado. A divisão de poderes dentro do Estado não deve ter a feição de unidades ou instituições políticas estanques e com funções correspondentes exclusivas e em separado. Trata-se de um sistema onde cada poder, subsistente por si, inclui dentro os outros em uma interdependência orgânica.

Estes momentos diferenciados, que constituem os poderes, são momentos ideais do todo, do qual se diferenciaram; na verdade, só podem existir em relação orgânica com o todo, e a vida própria de qualquer deles seria impensada e constituiria superabundância prejudicial ao todo. Para Hegel, 
quando se fala em separação ou independência dos poderes, há que se ter em conta que esta delimitação constitui, na verdade, apenas momentos do conceito. Posto que, se constituíssem unidades verdadeiramente independentes, isto acarretaria em conflito, o que destruiria o todo. Ao final da adição ao § 272 da Filosofia do Direito lê-se: "Com a independência dos poderes, por exemplo, dos chamados poderes executivo e legislativo, está imediatamente posta a desintegração do Estado". De tal conflito somente seria restabelecida a harmonia pela força. Ao contrário disto, no contexto das instituições políticas da Inglaterra, temos a experiência em que os ministros são, ao mesmo tempo, membros do parlamento, estando assim, em conexão com o legislativo e não em oposição a este (FD, § 300, adição).

\section{c) A centralidade da Constituição}

Pierre-Jean Labarrière e Gwendoline Jarczyk (1989), a partir da leitura do $\S 260$ da Filosofia do Direito, ao analisarem aquilo que Hegel chama a Constituição interior, entendem que ele centra sua reflexão sobre o que se pode chamar o silogismo do poder, o que permitirá, inclusive, determinar qual o lugar do povo dentro deste silogismo e, até mesmo, responder se é possível que seja concebida uma democracia nos termos do hegelianismo. Aqui se trata, portanto, de compreender o Estado no sentido especulativo da Lógica, ou como diz Hegel, enquanto efetividade da liberdade concreta.

Para tanto, explicam os autores que Hegel trata de expor a articulação interior entre 0 universal e o particular; ou seja a relação dialeticamente recíproca entre objetivos privados e públicos como base de um "nexo social" que vai além do agir "pessoal". E, neste sentido, a Constituição é vista como um conjunto de interações que se estabelecem a partir das instituições que antecedem o Estado, tais como a família e a sociedade civil.

Labarrière-Jarczyk atentam para o fato de que em Hegel, o Estado político, enquanto forma última da eticidade, se determina segundo uma ternariedade silogística de engrenagens sociais que são suas próprias diferenças substanciais. Para enumerar estas diferenças, afirmam os autores, Hegel propõe um silogismo de natureza complexa, cuja forma geral - universal/particular/singular - fará lembrar um simples silogismo de inclusão, tratando-se, no entanto, de um movimento que vai da extensão máxima à compreensão dos elementos deste percurso na pessoa do príncipe, em que se precipitam e se refletem idealmente aqueles diferentes poderes.

Estes autores fazem ver que, embora a ordem de apresentação destes poderes, conforme $0 \S 273$, inicialmente, permita uma leitura que induz à forma geral do silogismo já mencionada - U/P/S - na verdade Hegel concebe a figuração silogística, partindo de dois começos: um que parte da forma universal-particular-singular e outro, da forma singular-particular-universal. Da mesma forma, como se referiu, importa, sobretudo, o movimento, o percurso especulativo que é próprio da substancia ética absoluta. 
Dado este duplo movimento da substância ética concebida por Hegel, não tem sentido a conjetura de que haveria uma incoerência na ordem de apresentação dos poderes, se comparados o § 273 com § 275. Na primeira fórmula de partida, o universal é o poder legislativo - localizado no povo e que tem, por finalidade, captar o universal fixando-o nas leis que se impõe a todos; o particular corresponde ao poder executivo (ou governamental) - que tem por função assegurar a transição entre aquelas normas gerais sancionadas pelo povo e os casos concretos que devem ser regrados. Em terceiro lugar, o poder do príncipe, corresponde ao singular, não só enquanto resultado do processo, mas também, enquanto coloca a unidade individual em posição mais alta e de começo do todo; como o ponto de retorno e reinício do processo, invertendo o percurso; o que institui o príncipe como uma figura simbólica na qual o povo se reconhece, de modo que, por isso, a autoridade do mesmo se encontra no povo. Dizem os autores:

0 universal que deve exprimir o político tem, portanto, sua fonte no povo; um povo que não é uma simples coleção de indivíduos [...] mas uma totalidade orgânica a quem cabe determinar sua particularidade e sua singularidade; uma totalidade que se verifica neste processo mesmo; é por isso que o princípio democrático, em Hegel, invoca sua expressão sob a forma de uma monarquia constitucional. (LABARRIĖRE-JARCZYK, 1989, 299).

A partir desta análise, os autores apresentam a seguinte equação: "Se 0 povo não tem valor enquanto tal sem o príncipe, este, por sua vez, não tem justificação ética sem uma referência ao povo a quem ele deve sua universalidade". Os autores estabelecem qual o tipo de monarquia que Hegel diz tratar-se de uma monarquia constitucional.

Em conclusão, os autores sublinham que Hegel, para caracterizar o político, não se vale dos critérios que são apontados, na atualidade, como pressupostos fundamentais para que se reconheça a democracia. Tais critérios são, segundo os autores: a) o princípio de que o povo é a origem do poder e, b) o de que a eleição dos representantes se deve dar mediante o sufrágio universal. Logo, se Hegel não toma estes critérios como referência para a afirmação da idéia republicana, atribuir-se ao filósofo alemão a pecha de antidemocratismo, pode revelar, pelo menos, um anacronismo, ou uma precipitação.

Dada a importância capital da Constituição na filosofia hegeliana, segundo Labarrière-Jarczyk, de maneira figurada, pode dizer-se que o personagem principal da configuração do político em Hegel não é o povo e muito menos o príncipe ou o governo, mas é a Constituição que configura o político. A Constituição é como uma entidade quase viva, que desenvolve suas próprias determinações de maneira especulativa. 0 equilíbrio constitucional é alcançado mediante a articulação dinâmica entre os momentos da singularidade do príncipe, da particularidade do governo e da universalidade do poder legislativo, entendidos estes momentos como a expressão política da organicidade que constitui o social em seu conjunto. 
Tendo apresentado os modelos constitucionais e a teoria hegeliana da Constituição, resta apresentar os desafios da Constituição face ao cenário da mundialização.

\section{4 - Constituição e desafios da mundialização}

A teoria constitucional foi sendo elaborada ao longo do tempo, a partir de temas tais como, a separação dos poderes, a Constituição-garantia, o conceito formal e material da Constituição, assembléia constituinte, alterações constitucionais etc. 0 quadro da história mais recente das experiências constitucionais apresenta alguns tipos distintos: Os Estados das democracias clássicas, inspirados nos princípios da democracia liberal; os ex-Estados socialistas; os Estados autoritários; os Estados de independência recente; os Estados reunidos em Comunidades de Estados, com uma Constituição comum, sem renunciarem à própria Constituição nacional, como, por exemplo, a Comunidade Européia; os Estados reunidos em blocos econômicos, sem uma Constituição, nos quais, porém, de fato, a Constituição enfrenta, freqüentemente, problemas de legitimidade e de funcionamento. Enfim, todos os Estados, de uma maneira ou de outra, colocam-se, atualmente, diante deste problema: Qual é o papel da Constituição, considerando que os Estados nacionais, surgidos com a modernidade, vêem-se solapados em sua soberania, pela formação crescente de sociedades transnacionais capitalistas que se organizam à revelia dos Estados e a partir de uma perspectiva desterritorializada e mundializante?

\section{1 - As instituições transnacionais e a Constituição}

A formulação hegeliana a respeito do idealismo da soberania, teria, no entender de Marcos L. Müller (2004) a função de moldar a organização político-constitucional do Estado soberano em seus poderes, definindo a atuação do mesmo no interior da sociedade civil; e apontaria para a necessidade de instituições de um poder público transnacional.

No caso das instituições públicas transnacionais, sua função seria regular as tendências auto-destrutivas da mundialização capitalista, que estão localizadas na sociedade civil transnacional, uma vez que suas forças são tão poderosas que conseguem impor-se sobre o Estado constitucional. Para fazer face a este poder transnacional da sociedade civil, Müller propõe a instituição de um poder público transnacional, enquanto uma instância do universal, tendo a função de "enquadrar" estas forças para que não destruam o Estado constitucional.

De fato, o autor, entende que a sociedade civil transnacional que se está formando poderá tornar-se um poder destruidor, alçando-se acima das 
soberanias nacionais particulares. Porém, isto pode ser evitado "se tiver à sua base esferas de universalidade e instituições públicas", com a finalidade de garantir à sociedade civil transnacional uma autonomia relativa a fim de que esta não se feche sobre suas particularidades, isto é, seus interesses e legitimações privadas. "É imperioso", continua o autor, pensar na superação categorial da sociedade civil transnacional através de instituições públicas transnacionais, ou seja, a formação de uma esfera universal oposta à esfera particular - sociedade civil transnacional. A necessidade da formação de instituições públicas transnacionais tem, por finalidade, opor-se à instrumentalização da soberania do Estado. Mais ainda, impedir o desmantelamento do espaço público da antiga soberania nacional. A sociedade civil transnacional pode ser uma ameaça de "desenvolvimento da particularidade subsistente por si", entregue exclusivamente à sua lógica, vindo assim a se auto-destruir, através da exclusão do "conceito substancial" (FD, $\S 185)$, que é a mediação do particular e do universal na singularidade.

Müller detecta o problema da contradição entre a sociedade civil transnacional e as instituições públicas transnacionais. A superação desta contradição é posta na afirmação da "idealidade da soberania", pois este conceito implica na "afirmação da superioridade do interesse público sobre os interesses particulares e da soberania política interna sobre os direitos de propriedade privada" $(2004,3)$. Reconhecendo que o conceito de soberania hegeliana foi elaborado dentro do horizonte do Estado moderno, ele levanta a hipótese de que 0 conceito de idealismo da soberania "pode fornecer elementos ou apontar direções que ultrapassam o horizonte do Estado-nação, para pensar a urgência da criação de esferas e organizações públicas transnacionais, que venham a enquadrar e a restringir os particularismos da propriedade privada que se reproduzem no interior da própria sociedade civil transnacional em vias de formação" $(2004,4)$.

Percebe-se que há uma contradição entre as instituições transnacionais privadas e públicas, pois, os interesses da sociedade civil transnacional opõem-se aos interesses das organizações públicas transnacionais. Ora, se a solução desta contradição, segundo a proposta de Müller, seria a criação de organizações públicas transnacionais, resta saber qual é seu estatuto jurídico-político, bem como o papel destas organizações? Pois, para Hegel a função de um juiz ou de um árbitro entre os Estados, e nós diríamos, de uma organização, é sempre contingente. Por isso o projeto kantiano de uma federação de Estados, da mesma forma permanece contingente (cf. FD, § 333). Seguindo, a teoria hegeliana constitucional, a solução desta contradição está na própria Constituição.

\section{2 - Condição do reconhecimento mundial: a Constituição}

Não seria o Estado constitucional a matriz que forneceria os elementos responsáveis pela mediação desta contradição, posta pela mundialização 
do capital? Qual o modelo de Estado Constitucional que poderia fazer face à tendência destruidora no interior da sociedade civil? Ou seja, como garantir uma nova configuração constitucional?

Hegel afirma o seguinte a propósito das bases do direito internacional: "O povo, enquanto Estado, é o espírito na sua racionalidade substancial e na sua realidade imediata [...]. A questão de saber se tal Estado é de fato um Estado, existindo em si e por si, depende de seu conteúdo, de sua constituição [o grifo é nosso], de sua situação, e o reconhecimento [o grifo é nosso], que implica uma certa identidade entre os dois Estados, repousa sobre o juízo e a vontade do outro" (FD, § 331). As condições para um Estado existir em si e por si, ou seja, afirmar-se, soberanamente, no cenário internacional, pelo visto, dependem, fundamentalmente, de sua Constituição.

A Constituição é um elemento central, como constatamos, ao longo da exposição, no fator de organização interna do Estado. Agora, ela constituise, da mesma forma, na identidade para o reconhecimento recíproco entre os Estados. Hegel ao enumerar os elementos que garantem a afirmação da identidade, os coloca na seguinte ordem lógica:

a) 0 conteúdo do "espírito do povo";

b) A Constituição;

c) A situação do "espírito do tempo";

d) 0 reconhecimento internacional.

Esta ordem proposta por Hegel, obedece a uma lógica: O conteúdo constitucional é o imediato posto como espírito do povo que compõe a substância da Constituição. Esta sempre é relacionada com a situação do espírito do tempo. Assim, articulados, o espírito do povo e o espírito do tempo pela Constituição, constituem um Estado em si e por si, em condições, portanto, de ser reconhecido pelos outros Estados. De fato, a Constituição nesta ordem aparece como sendo o elemento que faz a mediação, pois realiza a interface entre o conteúdo constitucional e a situação do tempo; o primeiro, contém os hábitos e costumes do povo com suas tradições e valores; enquanto, o segundo é portador das inquietações do presente, buscando a realização do que deve ser conforme ao conceito da Constituição.

Ao longo do texto, chegamos a duas constatações:

1a) A experiência histórica dos três modelos de Estado constitucional: Liberal de Direito, Social de Direito e Democrático de Direito constituíu-se dentro de um quadro de Estado-Nação moderno. Aqui, a Constituição é um organismo garantidor da soberania e dos direitos do cidadão.

2a) Nos modelos contemporâneos, para pensar a democracia e a Constituição foi exposto o debate entre liberais e comunitários. De um lado, para 0 modelo liberal, o indivíduo é o "valor primário e referencial da sociedade humana", sendo a Constituição o instrumento garantidor do mesmo. De 
outro lado, no modelo comunitário, a democracia participativa junto com uma Constituição-projeto priorizam as identidades coletivas. 0 modelo da política deliberativa proposto por Habermas aponta os limites dos dois modelos anteriores, e propõe uma "forma parlamentar de aconselhamento e decisão fundada na ação comunicativa da opinião pública de cunho político". Ora, a análise da teoria hegeliana constitucional nos conduziu ao seguinte desafio: Em contexto de mundialização assimétrica, é possível a inserção soberana na política global? Ou seja, os Estados nas suas relações internacionais são levados a possuir uma estratégia de inserção mundial soberana. Ora, qual é a função da Constituição, para inserir o Estado soberanamente na política internacional, buscando relações globais e plurais, em defesa dos interesses nacionais e da formação de um novo espaço político internacional de caráter democrático?

Uma resposta convencional afirma que é necessário promover o fortalecimento de blocos regionais, através da coordenação de políticas macroeconômicas, da harmonização das legislações nacionais, do livre trânsito de pessoas, bens, capitais e mão-de-obra e, sobretudo, da institucionalização de mecanismos de funcionamento, avançando, na integração dos países.

A resposta hegeliana afirma que a organização constitucional do Estado acontece em dois momentos, a partir da articulação dos interesses privados (organização sócio-jurídica) e dos interesses públicos (organização ético-política). Portanto a teoria hegeliana da Constituição, diante deste cenário da mundialização, com seus desafios e propostas, prioriza os elementos da identidade constitucional como uma garantia e condição de reconhecimento mundial. Ou seja, somente o Estado, que estiver, bem resolvido, constitucionalmente, poderá fazer uma inserção soberana e autônoma neste atual estágio de correlação de forças, quer em nível regional, quer mundial.

\section{Referências bibliográficas}

ACKERMAN, Bruce. La justicia social en el Estado liberal. Tradução Castelhana de Carlos Rosenkrantz. Madrid: Centro de Estudios Constitucionales, 1993.

A interpretação constitucional na filosofia política contemporânea. In: CAMM ARGO. Margarida M aria Lacombe. (Org). 1988 - 1998: uma década de Constituição. Rio de Janeiro: Renovar, 1999.

Argumentos Filosóficos. Tradução de Adail U. Sobral. São Paulo: Loyola, 2000.

. Direito e democracia: entre facticidade e validade. V. I. Tradução de Flávio Beno Siebeneichler. Rio de Janeiro: 1997. 
- La diversidad de bienes. La Política: revista de estudios sobre el Estado y la sociedad, Barcelona, Paidós, n. 1, 1996.

- La politica del dialogo liberal. Tradução Castelhana de Gabriela L. Älonso Barcelona: Gedisa, 1999.

. Liberalismos políticos. DOXA, Madrid, n. 17-18, p. 25 - 51, 1995.

Propósitos cruzados: el debate liberal-comunitário. In: ROSENBLUM,

Nancy L. (dir.) El liberalismo y la vida moral. Tradução de Horacio Pons. Buenos Aires: Nueva Visión, 1991.

BOBBIO, Norberto. Estado, Governo, Sociedade. Por uma teoria geral da política. São Paulo: 1999.

BO BBIO, Norberto. Estudos sobre Hegel. Direito, Sociedade Civil, Estado. São Paulo: Brasiliense, 1991.

BOLZAN DE MORAIS, José Luis. As crises do Estado e da Constituição e a transformação espacial dos direitos humanos. Porto Alegre: Livraria do Advogado, 2002.

BONAVIDES, Paulo. Curso de Direito Constitucional. 13. ed. São Paulo: Malheiros, 2003.

BOURGEOIS, Bernard. Le Droit Naturel de Hegel (1802-1803). Commentaire. Contribuition à l'étude de la genèse de la spéculation hégélienne à lena. Paris: Vrin, 1986.

CITTADINo, Gisele. Pluralismo, direito e justiça distributiva: elementos da filosofia constitucional contemporânea. 2 ed. Rio de Janeiro: Lumen Juris, 2000.

ELOSEGUI, Maria. La inclusión Del outro. Habermas y Rawls ante las sociedades multiculturales. Revista de Estudios Políticos Nueva Época. N. 98, 1997. (Tradução Nossa).

GARGARELLA, Roberto. Las teorias de la justicia después de Rawls: un breve manual de filosofia política. Barcelona: Paidós, 1999.

HABERM AS, Jürgen. A inclusão do outro: estudos de teoria política. Tradução de George Sperber e Paulo Astor Soethe. São Paulo: Loyola, 2002.

HEGEL, G.W.F. Enciclopédia das Ciências Filosóficas. São Paulo: Loyola, 1995, v.l. (Abreviação: Enc)

HEGEL, G.W.F. Principes de la Philosophie du Droit. (Tradução de JeanFrançois Kérvegan). Paris: PUF, 1998. (Abreviação: FD; Tradução dos textos foi feita pelos autores)

KERVÉGAN, Jean-François. Hegel, Carl Schmitt: Le politique entre spéculation et positivité. Paris: PUF, 1992.

LABARRIÈRE, Pierre-Jean e JARCZYK, Gwendoline. Le syllogisme du pouvoir. Paris: Aubier, 1989. 
MÜLLER, Marcos Lutz. Estado e Soberania: O idealismo da soberania. Disponível em: http:// geocities.yahoo.com.br/matrizeshegelianas/ estadoesoberania.html, acessado em $13 \mathrm{dez}$. de 2004.

NINO, Carlos S. Kant versus Hegel, otra vez. La Política: revista de estudios sobre el Estado y la sociedad, Barcelona: Paidós, n. 1, 1996.

RAMOS, César Augusto. Liberdade subjetiva e Estado na filosofia política de Hegel. Curitiba: Editora da UFPR, 2000.

ROSENFIELD, Denis. Política e liberdade em Hegel. São Paulo: Editora Brasiliense, 1983.

RUSSOMANO, Rosah. Curso de Direito Constitucional. São Paulo: Saraiva, 1972.

TAYLOR, Charles. El multiculturalismo y la politica del reconocimiento. Tradução castelhana de Mónica Utrilla de Neira. México: Coleción Popular, 1993.

WOLKMER, Antonio Carlos. Pluralismo jurídico: fundamentos de uma nova cultura no Direito. 3. ed. São Paulo: Alfa Omega, 2001. 